\title{
UMA NAÇÃO E UM POVO NAS PÁGINAS LITERÁRIAS
}

\author{
A NATION AND ONE PEOPLE IN THE LITERARY PAGES
}

\author{
Sandra Mara Dantas* \\ sandramdantas@hotmail.com
}

\begin{abstract}
RESUMO: Assim como outros países latino-americanos, no século XIX, o Brasil tornou-se independente da metrópole europeia. Daí em diante, a busca pela constituição de uma identidade nacional foi assaz recorrente e a literatura cumpriu importante papel. Especialmente, no último quartel do século $\mathrm{XIX}$ e primeiras décadas do século $\mathrm{XX}$, é possível identificar diferentes nuances na pena dos literatos para dar forma à nação e ao brasileiro. Intelectuais de diferentes matizes contribuíram de modo significativo para pensar a realidade e em ato contínuo, elaborando um discurso acerca da identidade como construção social e histórica. E como documento histórico, a literatura é uma representação que registra e expressa aspectos múltiplos da realidade a que se refere. Ela configura, poeticamente, a realidade e desvela as condições e as representações da sociedade, infunde novos valores e noções que incitam à transformação e/ou reafirmam a ordem social. Nesse sentido, o foco desse artigo é refletir a respeito do papel da Literatura no processo de constituição da identidade nacional no Brasil.
\end{abstract}

PALAVRAS-CHAVE: História e Literatura, Identidade Nacional, Lima Barreto.

ABSTRACT: In the 19th century, as other Latin American countries, Brazil beame independent from its European Metropolis. After that, the search for the constitution of a national identity was highly common and the literature played an important role. Specially, from the end of the 19th century to the first decades of the 20th century, it is possible to see different aspects in the scholars way of writing to outline the nation and its citizens. Intellectuals from different tendencies were very important to think the Brazilian reality and create a speech about its identity as historical and social constitution. The Literature is a historical document and expresses a lot of aspects of reality. Poetically, it creates the reality and reveals the conditions and the representations of society, inspires new values and notions to change or to keep the social order. Anyway, thinking about the function of Literature in the process of national identity make up in Brazil is the reason of this article.

KEY-WORDS: History and Literature, National Identity, Lima Barreto.

Não cabe ao historiador restaurar as experiências humanas em sua totalidade visto não haver verdade absoluta. É seu ofício recuperá-las pelos diferentes vestígios que os homens produziram ao longo de sua trajetória e que resistiram à ação deletéria do tempo. Em seu ofício, o historiador utiliza de diferentes documentos porque, como ensinou Marc Bloch, "tudo que o homem diz ou escreve, tudo que fabrica, tudo que toca pode e deve informar sobre ele" (BLOCH, 2001, p. 79).

*Doutora em História Social pela Unesp/Franca. Professora Adjunta do Departamento de História da Universidade Federal do Triângulo Mineiro 
O documento histórico é uma seleção efetuada pelo historiador, dentre um conjunto de indícios deixados pelos homens e necessita ser criteriosamente analisado; pois "não é qualquer coisa que fica por conta do passado, é um produto da sociedade que o fabricou segundo as relações de forças que aí detinham o poder" (LE GOFF, 2003, p.536). Sua conservação ao longo do tempo pode ter ocorrido por diferentes razões (propositais, circunstanciais, ou mesmo alguma excentricidade) e sua utilização para responder às perguntas que o presente the apresenta requer análise, decifração até, pois procede do modo determinado que uma sociedade concebeu o mundo. Isto é, há um diálogo entre o presente e as fontes pretéritas.

Por longo período, somente os documentos escritos, preferencialmente os institucionais, eram válidos no ofício do historiador caracterizado pela busca, seleção e classificação documental. A maior preocupação consistia em obter a verdade, reconstituir o fato ocorrido, pressupondo a imparcialidade do pesquisador na realização de uma série de operações técnicas (crítica interna e externa); em que o sujeito e o objeto do conhecimento são dissociados. Em um contexto de afirmação das ciências, a preocupação dos historiadores metódicos - ditos positivistas - era validar a história científica e, assim, qualquer testemunho involuntário ou que expressasse alguma subjetividade não seria confiável.

Segundo os manuais dos historiadores positivistas Ch. Langlois e Ch. Seignobos redigidos no final do século XIX - o método assegura a consecução da objetividade histórica e a escrita da história se caracteriza pela exposição científica dos fatos acontecidos, sem quaisquer resquícios ficcionais ou imaginativos. A esse postulado, uma crítica se eleva sob o princípio de que "teoria e método desenvolvem-se em reciprocidade" (GRESPAN, 2005, p.295). Assim, o movimento historiográfico do final dos anos 1920, os Annales, considera que na escrita da História, nas palavras do historiador francês Lucien Febvre:

A história faz-se, sem dúvida, com documentos escritos, quando eles existem; e, até mesmo, na sua falta, ela pode e deve fazer-se. A partir de tudo o que a engenhosidade do historiador pode lançar mão para fabricar seu mel, na falta de flores usuais. Portanto, a partir de palavras e sinais; de paisagens e pedaços de argila; das formas de campos e de ervas daninhas; dos eclipses de lua e das coleiras de parelha; da perícia de pedras feita por geólogos e da análise de espadas metálicas por químicos. Em suma, a partir de tudo o que, pertencente ao homem depende e está a serviço do homem, exprime o homem, significa a presença, a atividade, as preferências e as maneiras de ser do homem. (FEBVRE, apud LE GOFF, 2003, p. 530) 
Essa "revolução" no conceito de documento histórico ampliou também o campo de atuação do historiador, sendo que as múltiplas dimensões da realidade podem ser alvo de estudos do historiador. E se antes, o ponto de partida era o documento, doravante, o problema move o sujeito do conhecimento. Um mesmo documento possibilita diferentes leituras e problematizações. "Muda mais o olhar sobre a fonte do que a fonte em si. [...] 0 que torna [o documento] relevante é a análise que se faz dele, não o documento em si." (KARNAL \& TATSCH, 2009, p. 16, 22)

A ampliação do conceito de documento exige uma nova erudição do historiador para lidar com as múltiplas linguagens, os suportes e os modos de conservação dos corpus documentais. O documento não é inócuo, sendo, inclusive transformado em documento/monumento à medida que é utilizado pelo poder. Daí a necessidade de crítica, desmontagem e desmistificação para apreender suas nuances e os sentidos construídos pelos sujeitos produtores - voluntária ou involuntariamente - para validar percepções e/ou imagens de si próprios e de sua sociedade.

Sob diferentes suportes, o documento é vestígio de experiências vividas que se traduzem em instituições, objetos, valores, arte, ideias, práticas e cabe ao historiador reconstituí-las em sua historicidade. É o historiador que em seu interesse por desvelar acontecimentos e ideias sobre as sociedades e seus sujeitos, tomam os documentos como fontes para, a partir de sua análise, construir uma explicação plausível a respeito.

A ampliação do repertório de fontes históricas apontou para novas possibilidades. Não somente os processos políticos e econômicos, os aspectos mentais, as subjetividades e o cotidiano ordinário podem ser historicizados. Por outro lado, isto exige uma postura interdisciplinar, o que constituiu um dos pilares dos fundadores dos Annales, os franceses M.Bloch e L.Febvre. E da história problema, as gerações seguintes alargaram o horizonte com novos objetos e abordagens que trouxeram para o campo de atuação do historiador, novas perspectivas dantes imaginadas.

É possível acessar o passado por grande variedade de testemunhos materiais, objetivos e subjetivos. Obras de arte, cartas, diários pessoais e literatura atravessadas por opiniões, parcialidades, críticas evidenciam o mundo social de seus produtores. Esse conjunto de fontes revela aspectos do imaginário social que, muitas vezes, outras não o 
permitem. E para apreender uma sociedade é imprescindível atentar para seu imaginário, isto é, seus hábitos, suas crenças, sua mentalidade.

O imaginário é uma das respostas que a sociedade elabora para expressar seus conflitos. É construído a partir das práticas sociais, é o local em que a comunidade reconhece sua identidade, elabora suas representações, distribui os papéis sociais e é uma das forças que regulam a vida coletiva tornando-se lugar e objeto dos conflitos sociais porque indica a posição dos diferentes grupos.

Os imaginários sociais constituem outros tantos pontos de referencia no vasto sistema simbólico que qualquer coletividade produz e através da qual ela se percepciona, divide e elabora os seus próprios objetivos. (...) 0 imaginário social elaborado e consolidado por uma coletividade é uma das respostas que esta dá aos seus conflitos, divisões e violências reais ou potenciais. (BAZCKO, 1985, p. 309)

A compreensão do imaginário social é fundamental visto que no cerne de seu controle está a legitimação do poder. Ele opera com o concreto, a razão e a sensibilidade; "torna-se inteligível e comunicável através da produção dos discursos nos quais e pelos quais se efetua a reunião das representações coletivas numa linguagem" (BAZCKO, 1985, p. 315). Desse modo, fornece aos agentes sociais, orientações expressivas e afetivas; conforma-os, convence-os, o que permite afirmar que, em certa medida, o controle do imaginário implica o controle do poder.

E nesse ponto, reside a singularidade da Literatura que nas palavras de Antonio Candido (1995), diz respeito a "todas as criações de toque poético, ficcional ou dramático em todos os níveis da sociedade", sendo um bem incompressível porque é fator de humanização, de instrução, de mobilização e de lazer. Ela é, também,

uma construção de objetos autônomos com estrutura e significado; é uma forma de expressão, isto é, manifesta emoções e a visão do mundo dos indivíduos e dos grupos, é uma forma de conhecimento, inclusive como incorporação difusa e inconsciente. (CANDIDO, 1995, p. 176)

Resultante do dialogismo social está historicamente situada e ao se apropriar dos inúmeros discursos, torna-se uma resposta artística às questões da realidade.

Como fonte histórica, a literatura enriquece o trabalho do historiador, reconhece-se a dimensão subjetiva no ofício, alarga as possibilidades de análise porque "detém a capacidade de abarcar as atividades materiais e espirituais dos homens, como seus sonhos, frustrações, angústias e utopias" (BORGES,1993, p.39). Mais do que um fenômeno estético, 
é um produto social que cria, também uma nova realidade; infunde valores e noções; articula as estruturas materiais e mentais.

A utilização da literatura como fonte histórica não constitui qualquer demérito ao ofício do historiador. É certo que durante algum tempo, o texto literário foi rejeitado pelos historiadores por seu "excesso" de subjetividade. A esse respeito, o historiador Antonio Celso Ferreira comenta:

Foi preciso compreender que a história também comportava dimensões subjetivas, imaginárias, oníricas e ficcionais, tão importantes quanto os acontecimentos políticos, sociais e econômicos. É verdade que o apelo aos textos literários ocorreu, inicialmente, em face da carência de outros documentos escritos que possibilitassem reconstruir a história das sociedades mais antigas. Contudo, logo os historiadores perceberam que eles também poderiam ser de grande valor para o estudo das culturas mais bem documentadas, justamente pelo fato de iluminarem terrenos obscurecidos nas demais fontes. (FERREIRA, 2009, p. 84)

Embora o reconhecimento das aproximações, as fronteiras entre história e literatura se mantêm. A lide com a literatura na oficina da História pressupõe uma postura interdisciplinar como defendida pelos fundadores dos Annales, na qual o historiador esteja atento às peculiaridades do texto literário, não somente em sua linguagem como na estética e nas condições de produção e recepção.

Conquanto assim como a História; a literatura tenha o homem como seu sujeito e sua produção seja influenciada pelos lugares sociais de seus autores, interaja com outros discursos para se (re)construir; ela possui alguns (e fundamentais) distanciamentos. A História privilegia o cotidiano vivenciado socialmente e atém-se aos fatos acontecidos ao passo que a literatura tem a liberdade de fabricar uma realidade ficcional em que o indivíduo tenha primazia sem compromisso com o verossímil. A intenção de produzir conhecimentos verdadeiros é típica do historiador e lhe permite assegurar a notoriedade de seu ofício em oposição aos falsários que querem anular a distinção ficção e história.

Mesmo que escreva em uma forma 'literária', o historiador não faz literatura, e isso, devido à sua dupla dependência. Dependência em relação ao arquivo, portanto em relação ao passado de que este é o traço. Dependência em relação aos critérios de cientificidade e às operações técnicas próprias a seu 'oficio'. (CHARTIER, 2002, p. 98) 
A assertiva do historiador Roger Chartier é uma resposta ao profícuo debate com os estruturalistas ${ }^{1}$ para quem o texto literário possui funcionamento automático e linguagem impessoal; ou seja, desconsideram sua historicidade. Ora uma abordagem histórica do texto literário necessita considerar a materialidade do texto e a corporalidade do leitor. Pela primeira, reconhece-se que os textos se dão a ler sobre formas determinadas e alterando o suporte, mudam seus sentidos. A segunda entende que a leitura não é uma prática descarnada, a recepção de um texto ocorre segundo os códigos e a 'comunidade de interpretação' a que pertence o leitor.

A linguagem é referencial e a experiência é irredutível ao discurso; há uma lógica que regula as práticas. A construção dos discursos é socialmente determinada e limitada pelos recursos (linguísticos, conceituais e materiais) que os sujeitos produtores possuem. A história é uma prática científica, produtora de conhecimentos e para tal depende de seus procedimentos técnicos; das vinculações com o lugar social e das regras de produção escrita. Abandonar a intenção de verdade é abrir margem ao questionamento do papel social do historiador e da história.

A defesa das distinções entre a História e Literatura manifestou mais intensamente no final do século $X X$, durante a comentada crise de paradigmas das Ciências Sociais. Chartier (2002) discute os desdobramentos dessa crise, advogando a perspicácia da História em incorporar saberes de outras áreas e, deste modo, fortalecendo-se dentre as demais Ciências Sociais, sem com elas se confundir. Sua principal asserção é do caráter científico da História, e assim a compreensão de que as práticas que criam o mundo social não se reduzem à construção linguística e que a construção dos discursos é "socialmente determinada, limitadas pelos recursos desiguais (linguísticos, conceituais, materiais)". Ao trabalhar com os textos literários, a tarefa do historiador é:

reconhecer a maneira como os atores sociais dão sentido a suas práticas e a seus discursos [considerando a] tensão entre as capacidades inventivas dos indivíduos ou das comunidades e, de outro lado, as restrições, as normas, as convenções que limitam - mais ou menos fortemente de acordo com sua posição nas relações de dominação - o que lhes é possível pensar, enunciar e fazer. (CHARTIER, 2002, p. 91)

\footnotetext{
${ }^{1} \mathrm{O}$ debate a que se dedica Roger Chartier tem como um de seus interlocutores, os teóricos do LinguisticTurn, especialmente o norte-americano Hayden White $(1995,2001)$ para quem a escrita da história é uma criação literária.
} 
O texto escrito é expressão de um conjunto de injunções no qual seu autor está imerso e o conhecimento histórico que se preocupa com os "modos como em diferentes lugares e momentos uma realidade social é construída, pensada, dada a ler"; preocupa-se em relacionar os discursos proferidos com a posição social de quem produz, visto que "as percepções do social não são de forma alguma discursos neutros: produzem estratégias e práticas que tendem a impor uma autoridade, um projeto, escolhas e condutas" (CHARTIER, 1990).

\section{Fatos históricos transformados em literatura}

A literatura é um produto artístico e também social, testemunho das transformações e delas se apropria na tentativa de compreender os homens e seu tempo. No Brasil do final do século XIX e início do XX as profundas transformações sociais impactaram nos modos de ver, de sentir, de observar, de exprimir, inculcando novas percepções na escrita literária e na produção artística. "Fruto das transformações, dedicada a refletir sobre [as transformações] e exprimi-las de todo modo, a literatura pretendia alcançar o seu controle, fosse racional, artística ou politicamente" (SEVCENKO, 2003, p. 287).

As manifestações literárias datam do período colonial; quando os escritos privilegiaram a ação dos bandeirantes na conquista e interiorização do território, descrevendo a exuberância da natureza tropical, as representações e práticas dos homens (indígenas e brancos). Após a independência do país, em 1822, tornou-se perceptível a inquietação em romper com as heranças lusitanas e construir uma identidade nacional genuína, uma brasilidade.

Os movimentos nativista, indianista e romântico foram exemplares na tentativa de configurar um pensamento social, uma leitura interpretativa da realidade ${ }^{2}$. Em sua fase romântica, alicerçada no ideário europeu, a produção literária procurou formular uma identidade positiva em que destacavam o indígena como tipo ideal, a opulência da natureza e a vinculação com a terra.

Outrossim, a criação do Instituto Histórico e Geográfico Brasileiro - IHGB (1838) agregou um conjunto de intelectuais de diversas formações no afã de revisitar a história e

\footnotetext{
${ }^{2}$ Aqui destacamos José de Alencar e seus romances Iracema e $O$ guarani para quem a origem do país está na união entre natureza e cultura, ou seja, entre os valores nativos e europeus; síntese do velho e do novo mundo.
} 
escrevê-la de modo a contribuir para criar uma identidade de nação (GUIMARÃES, 1988). Herdeiros da tradição iluminista do século XVIII, da história "mestra da vida" (magistra vitae), os membros do IHGB - historiadores, literatos, artistas e políticos - representavam a elite branca e sentiam-se comissionados a instruir o povo em um destino linear e progressista em que o índio e o negro, principalmente, são colocados em plano subalterno. Destarte, a história da nação tem seus sujeitos privilegiados. Para além da formulação de uma historiografia legitimadora das decisões políticas, o IHGB se lançou "à tarefa de escrever uma história nacional" e, simultaneamente, direcionar o futuro.

Os "homens de letras" envolvidos com a questão nacional não se restringiram ao IHGB, na segunda metade do século XIX, acentuou-se a preocupação com a definição dos traços de brasilidade. Diante das ideias cientificistas e filosóficas do período, parecia ser imprescindível firmar-se como Estado-nação afinado à modernidade (BERMAN, 1986). Esta é aqui compreendida como o conjunto de alterações que avassalaram o mundo ocidental ao longo dos Oitocentos, com ênfase na valorização da vida urbana, da ciência e da técnica, e nos valores do progresso e da civilidade.

Em consonância ao contexto então vigente na maior parte do mundo ocidental, é possível identificar uma série de alterações nas terras brasílicas: entrada de imigrantes europeus que corroborou a discussão pela abolição e introdução do trabalho livre e assalariado; aceleração do processo de industrialização, de urbanização e de modernização com os capitais acumulados com a expansão da economia cafeeira; a substituição do regime monárquico pelo republicano, reputado como único capaz de desenvolver as inúmeras potencialidades do país; o fortalecimento e a difusão de novas concepções de homem e de mundo que propugnavam novos tempos marcados por ascendente progresso tecnocientífico que extravasava o campo dos avanços materiais e tocava as sensibilidades em uma expectação por um risonho futuro.

Em Pernambuco, a conceituada Faculdade de Direito do Recife que teve importante papel na formação de juristas e de quadros políticos administrativos do país, nasceu o movimento conhecido como Escola do Recife ${ }^{3}$ que constituiu lócus produtor e difusor de um pensamento social, calcado nas ideias positivistas e evolucionistas. Esse movimento buscou

\footnotetext{
${ }^{3}$ A esse respeito ver SCHWARCZ, Lilia. O espetáculo das raças: cientistas, instituições e questão racial no Brasil. 1870-1930. São Paulo: Companhia das Letras, 1993.
} 
interpretar o Brasil e marcar a identidade nacional como distinta da antiga metrópole lusitana e, concomitantemente, próxima das nações civilizadas.

Do nordeste do país para a região sudeste, nas imediações da sede da Corte, as ideias cultivadas na Escola do Recife vicejaram e marcaram uma geração que ficou conhecida como Geração de 1870, composta por intelectuais de diferentes matizes (liberais, abolicionistas e republicanos) que "postavam-se como os lumes a indicar o único caminho seguro para a sobrevivência e o futuro do país" (SEVCENKO, 2003, p. 102). São parte dessa Geração importantes nomes como Silvio Romero, Tobias Barreto, Castro Alves, Olavo Bilac, Joaquim Nabuco, Capistrano de Abreu, Lima Barreto, Machado de Assis, dentre outros.

Para os homens dessa Geração era necessário atualizar a sociedade, esquecendo as tradições e heranças coloniais e/ou imperiais, modernizar as estruturas da nação e elevar o nível cultural da população e mostrando-se afinados com a cultura europeia. Enfim, arvoravam-se uma espécie de vanguarda.

A Geração de 1870 viu no engajamento social e político, o principal meio para transformar o país e acreditava ser porta-voz de uma era de mudanças diante de uma sociedade de analfabetos e de uma "velha" elite. Tal postura foi favorecida pelo contexto da época como a teoria darwinista, as revoluções tecnológica e sanitária que favoreceram o processo de urbanização, a universalização das correntes europeias nas artes (Belle Époque francesa e a art nouveau). Havia uma "sensação de aceleração do tempo" que parecia demandar profundas alterações para olvidar o passado e suas estruturas, a escravidão, a monarquia, a vida rural e o analfabetismo. Assim, no último quartel do século XIX, um vocábulo parecia sintetizar os vários anseios, "república [que] expandiu seu campo semântico incorporando as ideias de liberdade, progresso, ciência, democracia, termos que apontavam, todos para um futuro desejado" (MELLO, 2009, p. 29).

Ao ânimo da proclamação da República, seguiu-se um desencanto. José Murilo de Carvalho (2001) assevera que os grupos que participaram do processo que culminou na proclamação eram divergentes e não ficaram satisfeitos com os contornos tomados. Era o "maxixe do republicano doido" que culminou em concepções díspares de cidadania e encarniçadas disputas a fim de tornarem suas representações válidas em face das demais.

A expectativa inicial, despertada pela República, de maior participação, foi sendo sistematicamente frustrada. Desapontaram-se os intelectuais com as 
perseguições do governo; desapontaram-se os operários com as dificuldades de se organizarem em partidos e de participarem do processo eleitoral. Todos esses grupos tiveram de aprender novas formas de inserção no sistema. Os intelectuais desistiram da política militante e se concentraram na literatura. (CARVALHO, 2001, p. 37)

A República que se construía amalgamava concepções antípodas tanto na fundamentação como no funcionamento, o que a historiadora Efigênia Resende (2010) denomina liberalismo oligárquico, isto é, durante os quarenta primeiros anos da experiência republicana, o sistema político estava baseado na dominação de uma minoria, ainda que uma constituição liberal estivesse em vigência.

As práticas oligárquicas alijaram não somente a maioria da população da participação política, os intelectuais foram "afastados do mundo político e das esferas de prestígio social", o que provocou um sentimento de malogro visto que se portavam como "mosqueteiros intelectuais".

Uma vez assentado o regime republicano e mortas as esperanças da 'Grande Mudança' em que todos depositavam sua fé, a condição do grupo intelectual diante das novas pressões pareceu oscilar entre a tradição engajada da 'Geração de 70' e a tendência à assimilação desvirilizadora da nova sociedade. (SEVCENKO, 2003, p. 129)

Não obstante, os "homens de letras" brasileiros, do final do século XIX e primeiras décadas do século XX, não eram uníssonos em suas posturas e reclames. É possível dispô-los em três principais grupos (SEVCENKO, 2003). Aqueles que assimilaram a nova sociedade dedicaram-se à imprensa e defendiam distância entre o escritor e o homem público; foram chamados vencedores ou intelectuais "de casaca". O segundo grupo eram os boêmios, ou ratés, que insistiam em um status especial ao "homem de letras". Por fim, os inconformados ou "escritores cidadãos", se supunham os legítimos sucessores da Geração de 1870 e tinham suas obras como instrumento político para conhecer a realidade e dirigir os rumos da sociedade.

Se na fase romântica houve uma idealização do homem e da terra brasileiros, caracterizando uma identidade positiva, a Geração de 1870 rompeu com tal perspectiva. A indicação de alguns temas como as raízes coloniais, a composição étnica do povo e a organização do Estado foram tomados como entraves ao processo de inserção do Brasil nos tempos modernos e civilizados. Doravante, certo pessimismo marcou a pena dos intelectuais porque “para a Geração de 1870, 'ser moderno' significava, sobretudo, buscar uma 
compreensão do significado de ser brasileiro; compreensão essa que deveria ser mediada pelo instrumental cientificista" (VELLOSO, 2010, p. 357).

É na transição e passagem de século XIX para o XX, instante de euforia com o moderno e o civilizado, que se acentuou no Brasil a preocupação com o futuro do país. Para Márcia Naxara (1992) esse é um período privilegiado em que se constitui um duplo confronto em que, diante de um mundo civilizado, o país busca estabelecer uma identidade própria. As imagens que foram se constituindo nesse processo eram dicotômicas, enquanto uma apontava para o progresso, possível graças ao urbano, as demais deveriam ser evitadas e o imaginário que emergiu influenciado por ideias evolucionistas, foi fortemente marcado pela negativação do brasileiro como homem indolente e não civilizado. Daí que o processo de construção da identidade brasileira foi marcado pela ambiguidade ora pela afirmação das positividades existentes, ora pela tentativa de abandonar o que era considerado feio, gerando o ressentimento de "sentir-se estrangeiro em sua própria terra".

A historiadora Bresciani (2001) afirma que as construções identitárias no Brasil, possuem lugares-comuns, o pecado de origem legado pelos colonizadores portugueses, a correlação homem-natureza que impediu o desenvolvimento das faculdades do homem brasileiro e a importação de ideias, costumes e hábitos. Tais lugares-comuns aparecem nos escritos de inúmeros intelectuais brasileiros, muitos deles herdeiros da Geração de $1870^{4}$. Se na vida pública, os intelectuais eram preteridos pelo que denominavam "mediocracia" funções públicas concedidas de acordo com os critérios oligárquicos e não meritocráticos buscaram interpretar o Brasil e utilizaram de suas penas para tal tarefa, marcando de modo indelével a construção da identidade nacional.

Na pena dos literatos, "os textos artísticos se tornaram termômetros admiráveis da mudança de mentalidade e sensibilidade" tornando possível ler "a história simultaneamente ao ato de ler a literatura, reproduzindo como pelo avesso o movimento de quem fez história fazendo literatura" (SEVCENKO, 2003, p. 287, 291).

A incompletude da identidade pode ser compreendida também pelas ambivalências que marcaram esse processo de construção. Inicialmente a valorização dos elementos naturais como detentores de potencial inefável para a riqueza de uma nação; ainda que as

\footnotetext{
${ }^{4}$ Dentre eles, menciona-se Joaquim Nabuco, Euclides da Cunha, Tavares Bastos e Manoel Bonfim.
} 
especificidades da população não foram consideradas. Posteriormente, o apontamento de certa negatividade tanto dos homens quanto dos elementos naturais, porém na ânsia de apontar perspectivas que contribuíssem para o progresso. Ambivalência porque o ideal e o real se mesclam, a realidade poderia ser transformada para construir uma nova e idealizada conforme os padrões modernos e civilizados.

E dentre os intelectuais que pensaram o país no período aqui privilegiado, destacamos Lima Barreto.

\section{Um país "estrambólico"}

Afonso Henriques de Lima Barreto, um mulato nascido no Rio de Janeiro em 1881, acompanhou as profundas transformações ocorridas na capital do país nas quatro décadas em que viveu. Vida vivida intensamente e eivada de contradições, frustrações e também alegrias. Filho de pais pobres ficou órfão de mãe ainda na infância e devido a doença mental de seu pai, deixou o curso de Engenharia na Escola Politécnica para sustentar a família. Colaborou em vários jornais e se tornou funcionário público (amanuense) no Ministério da Guerra. De espírito crítico e escrita prolixa, produziu inúmeras obras, dentre as quais se destacam: Recordações do escrivão Isaías Caminha; Triste fim de Policarpo Quaresma; Numa e a ninfa; Vida e morte de M. J. Gonzaga de Sá; Clara dos Anjos e Os bruzundangas. De vida conturbada, com problemas com bebidas e aceitação entre os intelectuais da época, não foi reconhecido enquanto vivia e morreu em 1922, ano simbólico para a produção artística brasileira 5 .

Lima Barreto viveu e produziu durante a Primeira República e não se furtou a pensar a sociedade que o circundava. A partir da cidade do Rio de Janeiro, como microcosmo do Brasil, refletiu sobre as estruturas e as subjetividades de seu tempo. Seus personagens, em sua maioria, eram os tipos sociais da população menos privilegiada economicamente (trabalhadores brasileiros e imigrantes pobres, mulatos, ex-escravos). E com ironia e irreverência, analisou o funcionamento da sociedade em seus meandros e suas

\footnotetext{
${ }^{5}$ No ano de 1922 aconteceu em São Paulo, a Semana de Arte Moderna, marco do Modernismo no país em que artistas de diferentes tendências, apresentaram suas obras como expressão de uma renovação na produção artística, que se queria genuinamente brasileira, marcada pela experimentação, pela liberdade criativa e pela modernização da linguagem. A esse respeito ver VELLOSO, Mônica. "O modernismo e a questão nacional" In: FERREIRA, Jorge \& DELGADO, Lucilia. O Brasil republicano. Vol. 1 . O tempo do liberalismo excludente. Rio de Janeiro: Civilização Brasileira, 2010.
} 
incongruências, ao mesmo tempo em que considerou a necessidade de superação para a constituição de um mundo melhor para todos.

É verdade que não possuía um projeto de transformação social, seu anseio era extravasar suas percepções acerca da realidade, e nesse exercício seus escritos desnudavam os inúmeros problemas e as transformações vividas pelos sujeitos sociais no início da República. (SEVCENKO, 2003) O projeto republicano em implantação era marcado pelo arrivismo, pelo domínio oligárquico, pela manutenção da estrutura autoritária e excludente, por significativo número de analfabetos sem acesso aos serviços básicos, por uma estrutura urbana deficitária e uma rural marcada pela extrema exploração do trabalho e precárias condições de produção. Não obstante, os grupos sociais dominantes no país propalavam um discurso ufanista de construção de uma nação civilizada, aos moldes europeus.

O Rio de Janeiro que Lima Barreto nos apresenta é, em suas próprias palavras, "estrambólico", espalhafatoso, incomum. A antiga cidade de aparência colonial cedeu espaço à metrópole moderna; espaços reformulados, demolições, expansão do sítio urbano, transferência de população para os subúrbios. E, concomitantemente, ao espanto provocado por essas modificações, o deleite provocado pela admiração das luzes no centro urbano, as construções arquitetônicas de aspecto monumental, os novos padrões sociais e culturais de comportamento e de circulação nos espaços, a formação de uma nova imagem do país.

Sua escrita é vibrante e, de certo modo, militante que não apenas expõe o contexto no qual se moviam seus personagens; analisa as representações e as práticas que norteavam os sujeitos sociais e as instituições. Foram alvos de sua "ácida pena": a política, a imprensa e a ciência. A primeira que despojava a maioria em favor de uma minoria de privilegiados; a segunda que se envolvia com os desmandos políticos e, em certa medida, controlava a opinião pública. Por último, a ciência por possuir caráter discriminatório que ratificava as teorias de superioridade e inferioridade racial e, por conseguinte, dificultava as possibilidades de os marginalizados galgarem os espaços sociais.

Se é possível identificar certo ressentimento em seus escritos, há, também, um realce para as representações dos setores marginalizados que nos apontam uma interpretação do Brasil; uma construção identitária que se relaciona mais ao sentimento de pertencimento e identificação do que a vinculação racial. Em um contexto que os grupos sociais dominantes não problematizaram as diferenças, almejando uma identidade 
homogeneizadora, os escritos de Lima Barreto são exemplares de uma reflexão mais aprofundada. Aqui, elegemos as obras Triste fim de Policarpo Quaresma e Os Bruzundangas para algumas rápidas considerações.

Triste fim de Policarpo Quaresma é um romance escrito, inicialmente em folhetins em 1911, em que "embora Lima Barreto teça os fios da narrativa com adornos de ficção, esse não perde o seu valor histórico, ele se ampara na verossimilhança" (COSTA, 2007:56). O personagem Policarpo Quaresma é um homem simples, funcionário público que acreditava na República e na força das ideias científicas como meio para tornar o país uma nação guiada pelo progresso. O romance apresenta as "venturas e desventuras" do personagem no processo de construção da República, desde a proclamação, da qual foi testemunha, até seu desalento com o governo provisório e como prenuncia o título, seu "triste fim".

Costa comenta que o valor do romance está em fazer "veicular a voz dos excluídos, dos amordaçados naquela sociedade e apontando a literatura como forma de denúncia, questionadora e que propunha soluções para as desigualdades sociais do país". (COSTA, 2007, p. 71) O autor se preocupa em demonstrar as representações e práticas dos grupos sociais excluídos, inclusive as relações que estabelecem com os demais grupos.

- Policarpo, você precisa tomar juízo. Um homem de idade, com posição, respeitável, como você é, andar metido com esse seresteiro, um quase capadócio - não é bonito! O major descansou o chapéu-de-sol e respondeu: - Mas você está muito enganada, mana. É preconceito supor-se que todo o homem que toca violão é um desclassificado. A modinha é a mais genuína expressão da poesia nacional e o violão é o instrumento que ela pede.

[...]

Ricardo Coração dos Outros gozava da estima geral da alta sociedade suburbana. É uma alta sociedade muito especial e que só é alta nos subúrbios. Compõe-se em geral de funcionários públicos, de pequenos negociantes, de médicos com alguma clínica, de tenentes de diferentes milícias, nata essa que impa pelas ruas esburacadas daquelas distantes regiões, assim como nas festas e nos bailes, com mais força que a burguesia de Petrópolis e Botafogo.

[...]

Para além do caminho, estendia-se a vasta região de mangues, uma zona imensa, triste e feia, que vai até ao fundo da baía e, no horizonte, morre ao sopé das montanhas azuis de Petrópolis. Chegaram à casa da velha. Ficava um pouco afastada da estrada. Bateram. - Que desejam? - Vovó estão aí dous "moços" que querem falar com a senhora. A sala era pequena e de telha-vã. Pelas paredes, velhos cromos de folhinhas, registros de santos, recortes de ilustrações de jornais. Não tardou vir a velha. Entrou em camisa de bicos de rendas, mostrando o peito descarnado, enfeitado com um colar de miçangas de duas voltas. - Boas-tardes. Minha velha, nós queríamos que 
você nos ensinasse umas cantigas. - Quem sou eu, ioiô! - Ora! Vamos, tia Maria Rita... você não perde nada... você não sabe o "Bumba-meu-Boi"? - E o "Boi Espácio"? - Cousa véia, do tempo do cativeiro - pra que sô coroné qué sabê disso? - É para uma festa... (BARRETO, p. 6, 10, 18; 1994)

O longo excerto acima é denotativo de que, para Lima Barreto, não havia uma matriz uníssona e ainda que não houvesse reconhecimento dos grupos sociais dominantes, as produções dos grupos economicamente excluídos eram incorporados e também, colaboravam no processo de construção da identidade nacional. Desde os grupos que viam a si próprios como ilustrados, portanto, dignos de dirigirem a nação; os grupos de setores médios que possuíam menos capital econômico, não obstante ansiassem por ocupar os espaços dos mais ricos; e os despossuídos que residiam nas periferias em construções precárias apropriavam-se, reciprocamente, das representações e desencadeavam práticas diversas que construíam seu mundo social. Nessa luta de representações, como ensinou Chartier (1990, p. 17):

as percepções do social não são de forma alguma discursos neutros: produzem estratégias e práticas (sociais, escolares, políticas) que tendem a impor uma autoridade à custa de outros, a legitimar um projeto reformador ou a justificar, para os próprios indivíduos, as suas escolhas e condutas.

Os grupos detentores de maior capital econômico e prestígio social lutavam por formular uma imagem imaculada do país, destituída de conflitos e de elementos populares, reputados como inferiores. Por outro lado, na interação que os grupos sociais mantinham entre si, havia uma luta em que elementos eram incorporados e/ou rejeitados. O violão, instrumento musical vinculado à população pobre, aos poucos foi sendo aceito entre os grupos mais ricos. Inicialmente, os setores médios como comerciantes e funcionários públicos, até chegar aos ricos salões da burguesia. À medida que as práticas iam sendo modificadas, as representações também o eram para corroborar os projetos elaborados e hierarquizar os grupos.

É certo haver o reconhecimento de uma luta de representações; mas neste cenário, as representações de outros grupos também vem à cena como visto na valorização dos negros e mulatos. De acordo com o trecho destacado do romance, Policarpo Quaresma e um coronel vão à periferia da cidade para falar com Maria Rita, uma mulata que conhecia os 
festejos e costumes populares como Bumba meu Boi ${ }^{6}$. A personagem reside em uma porção esquecida da cidade, "uma zona imensa, triste e feia" em que os benefícios da urbanização não chegaram e sua casa não possui aspecto aprazível de decoração aos moldes da Belle Époque como na região central. Com tal descrição, é possível ao leitor perceber que naquele período histórico, aos pobres restavam as regiões periféricas das cidades com carência da estrutura urbana, entretanto, pululava vida porque seus habitantes possuíam saberes diversos que poderiam ser partilhados com outros.

O desapontamento com a República em construção visto que os projetos elaborados não se consolidaram e o país que se esboçava estava amparado na contradição, gerando um sentimento ambivalente, ora de entusiasmo, ora de ressentimento. Ambivalência que também pode ser visualizada na obra Os Bruzundangas.

Sátira, escrita em 1915 e publicada em 1917, Os Bruzundangas ${ }^{7}$ descreve as impressões do narrador do tempo que viveu no país fictício, chamado Estados Unidos da Bruzundanga; onde as instituições, os valores e as produções, e os sujeitos são marcados por vícios. O leitor logo identifica não somente o país fictício com o Brasil Republicano do início do século XX, como seus homens reais em suas práticas políticas, sociais e culturais.

Como "escritor-cidadão" (SEVCENKO, 2003), Lima Barreto acreditava que suas obras eram instrumento político para crítica e análise da realidade, que para além de apontarem as contradições, indicassem perspectivas. Por isso, ao longo de seu texto, identificamos referências críticas a vários aspectos do país que parecia se localizar na "civilizada" Europa:

Há diversas espécies de escolas mantidas pelo governo geral, pelos governos provinciais e por particulares. Os meninos ou rapazes, que se destinam a elas, não têm medo das dificuldades que o curso de qualquer delas possa apresentar.

$[\ldots]$

\footnotetext{
${ }^{6}$ Bumba meu Boi é uma dança folclórica marcante na cultura brasileira, principalmente na região Nordeste. A dança surgiu no século XVIII, unindo elementos das culturas europeia, africana e indígena, como uma forma de crítica à situação social dos negros e índios. Ela combina elementos diversos como a dança e o teatro, com personagens fantásticos como a demonstrar a fragilidade do homem e a força animal.

7 "Bruzundanga ou burundanga é um brasileirismo que significa palavreado confuso, algaravia, mixórdia, trapalhada. A república dos bruzundangas seria, por conseguinte, o país das trapalhadas." ROMÃO, Ana Paula de Freitas. Os Bruzundangas: uma alegoria da 1a República. 2012. Dissertação (mestrado) - Universidade Estadual Paulista, Instituto de Biociências, Letras e Ciências Exatas, 2012.
} 
Conseguem sair-se da alhada e lá vão, cinco ou seis anos depois, ocupar gordas sinecuras com a sua importância de "doutor".

[...]

Passando assim pelo que nós chamamos preparatórios, os futuros diretores da República dos Estados Unidos da Bruzundanga acabam os cursos mais ignorantes e presunçosos do que quando para lá entraram. São esses tais que berram: "Sou formado! Está falando com um homem formado!" Ou senão quando alguém Ihe diz: - "Fulano é inteligente, ilustrado...", acode o homenzinho logo: - "É formado? - Não. - Ahn! Raciocina ele muito bem. Em tal terra, quem não arranja um título como ele obteve o seu deve ser muito burro, naturalmente. (BARRETO, 1998, p. 59-60.)

A denúncia da valorização da aparência de poder e a obsessão por títulos são latentes no trecho. Há uma preocupação em romper com as heranças colonial e imperial e a construção da nação que estava incompleta. Se antes as diferenças sociais estavam fundamentadas no nascimento que conferiam os títulos nobiliárquicos, a partir da República, a fórmula encontrada para manter as distinções foi o título acadêmico de doutor para aqueles que possuíam formação em nível superior e/ou ocupavam função pública. 0 excessivo apego ao título formou uma "nobreza doutoral" que desprezava o saber legítimo e, concomitantemente, assegurava prestígio social.

As escolas - espaço de conhecimento e ilustração - parecem não ser valorizadas por sua função, mas pela possibilidade de concessão dos títulos. Ou seja, o saber acumulado não era considerado útil, o importante era a decorrência do título auferido e que permitiria ocupar função prestimosa.

Ao apresentar a particularidade da educação em Bruzundanga, Lima Barreto evidencia a realidade da educação no país, essa que era privilégio das famílias e sujeitos que possuíam capital econômico, visto que nos primeiros anos da República, o acesso das classes populares era bastante restrito. Fato contraditório, uma vez que era recorrente a argumentação da necessidade de ilustração aos diferentes grupos para corroborar a jornada do país dentre as nações civilizadas. Por isto, a maioria da população estava excluída da participação política, pois além de estar impedida de votar, não podia ocupar postos e cargos públicos e institucionais.

$\mathrm{Na}$ "República dos letrados", contraditoriamente, pouco eram de fato letrados, visto que a produção intelectual não era bem quista e os ocupantes de cargos públicos não eram, necessariamente, competentes nos saberes acadêmico e/ou político-administrativo. A 
prática usual era de favorecimentos em que em troca de apoio, determinados sujeitos eram conduzidos a inúmeras funções, inclusive de alto escalão.

Não somente no fragmento acima como ao longo da obra, é notória a crítica barretiana à supressão dos setores populares e marginalizados da história do país. $\mathrm{Na}$ ausência da menção, a presença se torna evidente. Nas narrativas e imagens divulgadas oficialmente, os sujeitos privilegiados são os grupos mais ricos e vinculados aos costumes europeus. A população pobre aparece como exemplaridade daquilo que deveria ser renegado como feio ou deformado ou sujo ou quase incivilizado. Todavia os marginalizados estavam presentes na construção da nação e de sua identidade, e suas formas e vozes podem ser desveladas na produção literária.

Dos personagens e cenário inventados, em Lima Barreto reconhecemos o próprio Brasil e seus escritos dizem respeito ao que ele próprio vivenciou: a exclusão, a marginalização, o preconceito, as injustiças, as expectativas com o novo regime e com o país. Independentemente do grupo social a que pertenciam, seus personagens (re)construíram imagens do ser brasileiro, diversamente do que idealizado pelos grupos sociais dominantes.

Em uma relação de troca e de cumplicidade; História e Literatura recriam o real vivido em um determinado tempo. Ambas dialogam e cabe ao historiador, respeitando as devidas fronteiras, utilizar da Literatura como fonte (ou objeto) com o mesmo cuidado que utiliza de outros documentos, tendo como ponto referencial a problematização e o diálogo com outras fontes, com outros discursos. As histórias contadas pelos literatos são passíveis de realidade porque estão inseridas em contexto sócio-temporal que Ihes dá sentido e plausibilidade, revelando o funcionamento da sociedade, assim como comentado por Sevcenko (2003) "transformando em fatos literários os fatos históricos".

A literatura brasileira da primeira fase da República (1889-1930) registrou as mudanças que impactaram a sociedade, sendo ela mesma fruto das transformações que queria, quase desesperadamente, compreender e controlar. Ao registrar as intenções e projetos (às vezes antagônicos) auxilia-nos a compreender o processo de construção da nação e de sua identidade. 
REFERÊNCIAS BIBLIOGRÁFICAS

BACZKO, Bronislaw. A imaginação social. In: LEACH, Edmund et all. Anthropos-Homem. Lisboa: Imprensa Nacional/Casa da Moeda, 1985.

BARRETO, Lima. Triste fim de Policarpo Quaresma. São Paulo: Scipione, 1994.

Os Bruzundangas. São Paulo: Martin Claret, 1998.

BERMAN, Marshall. Tudo que é sólido desmancha no ar. A aventura da modernidade. São Paulo: Companhia das Letras, 1986.

BLOCH, Marc. Apologia da História ou o ofício do historiador. Rio de Janeiro: Jorge Zahar, 2001.

BORGES, Valdeci Rezende. História e Literatura: algumas considerações. Revista de Teoria da História. Ano 1, n.3, jun. 2010, p. 94-109.

- História e Literatura: uma relação de troca e cumplicidade. História e Perspectivas. n. 9, jul/dez.1993. Uberlândia: Edufu. p. 31-42.

BRESCIANI, Stella. Identidades inconclusas no Brasil do século XX - fundamentos de um lugar-comum. In: BRESCIANI, S. \& NAXARA, M. (orgs) Memória e (res)sentimento. Indagações sobre uma questão sensível. Campinas: Unicamp, 2001.

CANDIDO, Antonio. O direito à literatura. In: . Vários Escritos. São Paulo: Duas Cidades, 1995.

CARVALHO, José Murilo de. A formação das Almas - O Imaginário da República no Brasil. São Paulo: Companhia das letras, 1990.

. Os bestializados: o Rio de Janeiro e a República que não foi. São Paulo: Companhia das Letras, 1987.

CHARTIER, Roger. À beira da falésia. A história entre certezas e inquietudes. Porto Alegre: UFRGS, 2002.

A História Cultural: entre práticas e representações. São Paulo: Difel, 1990.

COSTA, Cléria Botelho. Progresso e desordem: o alvorecer da República brasileira. In: HOMEM, Amadeu et. al. Progresso e Religião. A República no Brasil e em Portugal. 18891910. Uberlândia: Edufu/Coimbra:Imprensa Universitária, 2007.

DÉLOYE, Ives. "A nação entre identidade e alteridade: fragmentos da identidade nacional" In: SEIXAS, J., BRESCIANI, M.S., BREPOHL, M. (orgs). Razão e paixão na política. Brasília: UnB, 2002.

FERREIRA, Antonio Celso. A fonte fecunda. In: PINSKY, Carla \& DE LUCA, Tania. O historiador e suas fontes. São Paulo: Contexto, 2009. 
GRESPAN, Jorge. Considerações sobre o método. In: PINSKY, Carla (org). Fontes Históricas. São Paulo: Contexto, 2005.

GUIMARÃES, Manoel Luiz Salgado. Nação e Civilização nos Trópicos: O Instituto Histórico e Geográfico Brasileiro e o Projeto de uma História Nacional. Estudos Históricos, Rio de Janeiro, n. 1, p. 5-27, 1988. Disponível em: http://bibliotecadigital.fgv.br/ojs/index.php/reh/article/view/1935. Acesso em: set 2015.

HAROCHE, Claudine. O que é um povo? Os sentimentos coletivos e o patriotismo do final do século XIX. In: SEIXAS, J., BRESCIANI, M.S., BREPOHL, M. (Orgs) Razão e paixão na política. Brasília: UnB, 2002.

KARNAL, Leandro \& TATSCH, Flavia. A memória evanescente. In: PINSKY, Carla \& DE LUCA, Tania. O historiador e suas fontes. São Paulo: Contexto, 2009.

LE GOFF, Jacques. História e Memória. 5.ed. Campinas: Unicamp, 2003.

MELLO, Maria Tereza C. A modernidade republicana. Tempo. Niterói, v. 13, n. 26, 2009. Disponível em: http://www.scielo.br/pdf/tem/v13n26/a02v1326.pdf. Acesso em: set 2015.

NAXARA, Márcia. Natureza e civilização: sensibilidades românticas em representações do Brasil no século XIX. In: BRESCIANI, S. \& NAXARA, M. (orgs) Memória e (res)sentimento. Indagações sobre uma questão sensível. Campinas: Unicamp, 2001.

A construção da identidade: um momento privilegiado. Revista Brasileira de História. v. 11, n. 23/24. São Paulo: ANPUH, 1991/1992.

PRADO, Maria Emilia. O Brasil dos intelectuais. Construções imagéticas e representações simbólicas - 1870/1920. In: SANTOS, Regma \& BORGES, Valdeci (orgs). Imaginário e representações: entre fios, meadas e alinhavos. Uberlândia: Asppectus, 2011.

PINSKY, Carla B. (org) Fontes históricas. São Paulo: Contexto, 2005.

RESENDE, Maria Efigênia L. O processo político na Primeira República e o liberalismo oligárquico. In: O Brasil Republicano. Vol.1. O tempo do liberalismo excludente. Rio de Janeiro: Civilização Brasileira, 2010. pp. 89-120

SEVCENKO, Nicolau. Literatura como Missão: tensões sociais e criação cultural na Primeira República. 2ed. São Paulo: Companhia das Letras, 2003.

VELLOSO, Mônica Pimenta. O modernismo e a questão nacional. In: FERREIRA, Jorge; DELGADO, Lucilia. O Brasil republicano. Vol. 1. O tempo do liberalismo excludente. Rio de Janeiro: Civilização Brasileira, 2010. 